BOOK REVIEW:

\title{
DEMOCRACY IN TURKEY: The Impact of EU Political Conditionality
}

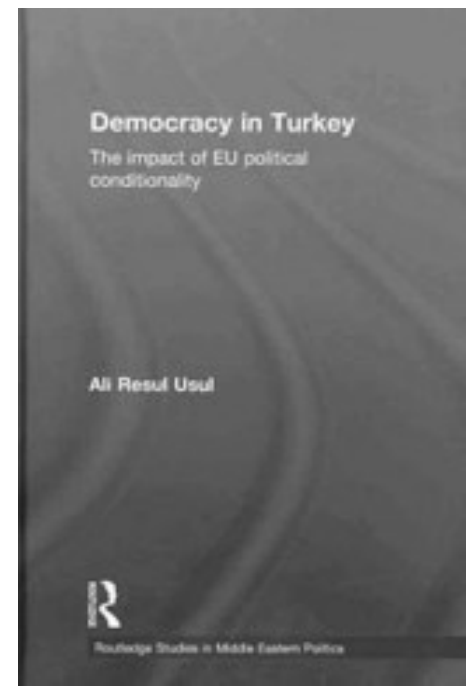

\section{ALİ RESUL USUL}

Routledge, 2011

Language: English

235 pages

ISBN: 978-0-415-56698-8

Studies on democracy and democratic consolidation have been dominating European studies for some time now. Especially upon the EU's success in transforming Central and Eastern European countries, it has become common place to work on these subjects. In Democracy in Turkey, Ali Resul Usul contributes to the democratization studies literature through elaborating the international context of democracy, conditionality, and democracy transfer through the case study of Turkey-EU relations. He analyses the impact of EU political conditionality on the process of democratization in Turkey in 1987-2007. He discusses the theoretical and conceptual dimensions of the concepts of democracy, democratic consolidation, and conditionality in a well-organized way. While analysing the effectiveness of EU conditionality in Turkey's democratization process, he divides the process into two historically crucial dates; pre-Helsinki period and postHelsinki period; in other words, he scrutinizes the democratization process of Turkey before and after its EU candidacy.

It should be noted at this point that the manuscript seems to be a slightly revised reprint of Usul's $\mathrm{PhD}$ thesis (Usul, 2003). As a matter of fact, its first chapter looks like a well-organized recapitulation of his $\mathrm{PhD}$ thesis. However, in its essence, it can be safely stated that the book contributes to the literature in a useful way with the analyses and arguments it provides to the reader. The book consists of five comprehensive chapters. The first chapter provides a theoretical and conceptual overview of international politics of democratic consolidation. The second chapter examines the nature and impact of EU political conditionality, the 
third chapter offers a case study; analysing EU conditionality and democracy in the pre-Helsinki period; the fourth chapter follows with the post-Helsinki period and the final chapters cover the impact of EU conditionality on Turkey. The major argument of the book is that EU conditionality remains limited to constitutional and legal domains in the case of Turkey. Usul describes Turkey's democracy as "fragile" and claims that despite some improvements, this "fragile state of democracy" still prevails. Moreover, in his view, when compared to the democratization processes of the Central and Eastern European Countries, the EU's effectiveness on Turkey's democracy remains significantly low.

Considering the methodology of the book, it can be stated that the writer adopts a meticulous literature review in the first two chapters. In the following chapters he also analyses the primary sources such as treaties, official documents and Regular Progress Reports. In the second chapter and in the following chapters he adopts a comparative analysis; comparing the situations of the Central and Eastern European Countries with each other and with Turkey's situation. It can be claimed that his methodology is quite relevant; however in the fifth chapter a more critical analysis might have been adopted. For example; in that chapter he refers to the Kurdish issue and the democratization process of Turkey in view of the EU reforms; yet his references to civil society and political culture seems insufficient. In the same chapter, one of his claims is the inefficiency of political conditionality of the EU in its relations with Turkey. According to Usul, it seems that in discursive practices, political conditionality sounds to be well-functioning. However, he could have supported this argument further by employing discourse analysis; revealing the gap between practice and discourse in this regard. Doing so would be a fine addition to the literature because there are already many studies on conditionality which are based on literature reviews and comparative analysis (cf. Saatçioğlu, 2009), as well as on quantitative analysis (cf. Schimmelfenning; Engert and Knobel, 2003).

On the other hand, Usul conducts an elaborate literature review on democracy and democratic consolidation. In the first chapter, he notes the historical background of civil society in Turkey. However, the third and the fourth chapters lack knowledge on historical background. Usul's statement on p. 141 is an example in this regard: "Turkish democracy, from the beginning, has been a story of a series of political crisis which have constantly hindered democratic consolidation in Turkey". However, these crises are hardly mentioned. Coups d'état are touched upon briefly; but readers might like to be informed about fluctuations of Turkish democracy more elaborately. Similarly, on p. 25, he refers to Putnam's and Gourevitch's arguments on democratization, but he does not establish the link between these arguments and the case of Turkey. It might have added more insight to the study if he could establish that link. 
Particularly in the first two chapters, there are too many voices, namely references, among them writer's own remains almost invisible. In the final chapter, where Usul touches upon the credibility of conditionality, there is no sufficient quantitative information. The book was published in 2011; and prior to that date, there existed empirical data on the credibility of the EU's conditionality, and he could have referred to them. Usul lists and analyses the factors which affect the efficiency of conditionality. However, he might have mentioned more about the credibility issue; which is one of the most important problems of Turkey-EU relations. Thus, one might argue that Usul could make more use of empirical data on the credibility of conditionality in Turkey-EU Relations. On the other hand, the second, third, and fourth chapters, which constitute the core of the book, are also the most well-organized and easy-to-read chapters.

The timeline of the book is also a bit problematic. Although it was published in 2011 , it only covers Turkey-EU relations until 2007. Being aware of the fact that preparing a manuscript for publication necessitates long periods; it can be claimed that the study would offer better insight into the EU's conditionality on Turkey if its time-frame had also covered the years 2008 and 2009. Because the writer claims that there is literature gap on the democratization process of Turkey regarding its relations with the EU; he could have attempted to defend this argument with references to recent developments both in the EU and Turkey. While doing so, he could have referred to the "democratic opening" or the local elections in Turkey, in 2009 and their implications for further democratization in Turkey.

Usul concludes that EU conditionality remains limited and ineffective in the case of Turkey when compared to the conditionality applied to Central and Eastern European Countries. He considers both the EU's share and Turkey's share in this inefficiency. The book gives the readers the idea that the whole democratization process of Turkey has its own sui generis momentum and dynamism especially when compared to the Central and Eastern European Countries. To conclude, it can be said that as is the case in most work in social sciences; there is a gap between theory and practice in studies on democracy/democratization. Usul's book contributes to the democratization literature with a review of almost 700 references. Despite some shortcomings, it definitely deserves to be considered as a "reference book" for both academics and researchers.

FATMANUR KAÇAR*

\footnotetext{
* Research Assistant, Marmara University, European Union Institute, Department of EU Politics and International Relations, e-mail: fatmanur.kacar@marmara.edu.tr
} 


\section{References:}

Saatçioğlu, B. (2009) "How Closely Does the European Union's Membership Conditionality Reflect the Copenhagen Criteria? Insights from Turkey", Turkish Studies, Vol. 10, No. 4, pp. 559-576.

Schimmelfennig, F., Engert, S. and Knobel, H. (2003) "Costs, Commitment, and Compliance. The Impact of EU Democratic Conditionality on Latvia, Slovakia, and Turkey”, Journal of Common Market Studies, Vol. 41, No.3, pp. 495-518.

Usul, A.R. (2003) "International Dimension of Democratization? The Influence of the European Union on the Consolidation of Democracy in Turkey 1987-2002". Unpublished PhD Thesis, Bilkent University, http://www.thesis.bilkent.edu.tr/0002280.pdf (Accessed 26.07.2014). 